\title{
Utilization of Fish Waste Processing as Compost Raw Material in Tambak Lorok Market
}

\author{
Ilga Mega Kusuma $^{1 *}$, Syafrudin ${ }^{2}$, and Bambang Yulianto ${ }^{3}$ \\ ${ }^{1}$ Master Program of Environmental Science, School of Postgraduate Studies, Diponegoro University, Semarang - Indonesia \\ ${ }^{2}$ Department of Environmental Engineering, Faculty of Engineering, Diponegoro University, Semarang - Indonesia \\ ${ }^{3}$ Department of Marine Sciences, Faculty of Fisheries and Marine Sciences, Diponegoro University, Semarang - Indonesia
}

\begin{abstract}
Fish waste needs to be a concern because the accumulation of fish waste will have environmental pollution. Therefore, research needs to be done to reduce the impact of environmental pollution. This study aims to treat fish waste which will be used as raw material for compost which is one of the efforts to reduce the accumulation caused by fish waste. The method used is survey, observation, and literature study. The composting process uses fish waste as a starter in the composting process. Before starting the composting is to separate fish waste from other wastes to facilitate the composting process. During composting the temperature conditions are maintained by reversing compost and color and odor changes are observed. The results showed that the levels of C-Organic; $51.7 \%$, Nitrogen; $8.3 \%$, Phosphor; $4.8 \%$, and Potassium; 1.6\%. From the results of C-Organic, Nitrogen, Phosphorus, and Potassium tests, the levels were quite high compared to the quality of SNI compost, so compost from fish waste where the Tambak Lorok Market can be used as fertilizer.
\end{abstract}

Keywords: Tambak Lorok; processing of fish waste; compost.

\section{Introduction}

Tambak Lorok is an area with the majority of the livelihoods of local people as fishermen. Tambak Lorok Market is a place where local people sell their own fish catches. Fishery products in the area play an important role in helping the economy of the Tambak Lorok community. The results of fishing are usually sorted according to the type and physical condition so that it is expected to meet consumer demand. However, not all fish caught can be utilized because of the large number of fish that must be wasted as waste. Fish waste is usually only stacked in several places, both at the fish auction site and in the Tambak Lorok market. In handling the fish waste it has not been done regularly so as to cause a foul odor that can pollute the surrounding environment. It is necessary to process fish waste to reduce the impact that will be caused to the environment, one of which is by utilizing fish waste as compost raw material. Compost from fish waste has the advantage of having nutrient content consisting of potassium, calcium, and magnesium. In addition, fish waste compost serves to maintain the quality of compost remains hygienic and free of contaminants such as heavy metals and phytotoxic compounds [1]. The remaining fish or wasted fish can still be utilized, namely as a raw material for organic fertilizer, where the fertilizer is of organic value, both organic-N, organic- $\mathrm{P}$, and organic-K contained in the body of the fish has advantages compared to other ingredients [2]. According to [3], prevention of the effects of pollution caused by the accumulation of rotten fish by BLHPP (Environmental, Gardening, and Urban Agency) of Samosir Regency in 2009 , by composting into fertilizer using EM4 as decomposing microbes. The compost produced has been tested by the Samosir Regency BLHPP in his corn demonstration garden and the results obtained are quite satisfactory compared to the plants owned by the surrounding community. One of the advantages of utilizing fish waste as compost is that it can overcome the problems regarding the disposal of fish waste into finished products that have a selling value and a green environment. Therefore, the processing of fish waste has the potential to be used as raw material for compost.

\section{Composting and Processing of Fish Waste}

\subsection{Fish Waste}

Fish waste is a biodegradable organic waste. The selection of fish waste as raw material composting is 
not without reason. This is due to fish including food that is easily decomposed so that the remaining ingredients in the form of fish head, fish meat fragments, fish entrails, fish fins, and tails if not handled carefully will cause a strong stench. The stench will invite many flies and can cause various diseases [4].

\subsection{Composting}

Compost is one of the organic fertilizers used in agriculture to reduce the use of inorganic fertilizers. The use of compost can improve soil physical properties and soil microbiology [5]. Compost has nutrients such as nitrogen and phosphate in the form of argon, protein and humic complexes which are difficult to absorb by plants [6].

\subsection{Fish Waste Management}

The process of making compost is by entering $2 \mathrm{~kg}$ of fish waste into a porous plastic container with a moisture content of $15.08 \%$ which has been mashed and left for 2 weeks (fish waste is used as a starter). Then mixed into a bucket containing the remaining vegetables and fruits.

\section{Research Method}

\subsection{Time and Place}

This writing study is located in Tanjung Mas Village, North Semarang District, Semarang City. The field survey was conducted on March 13, 2019. The research method consisted of methods of observation, interviews, and literature. Unstructured interviews with related parties (Tambak Lorok fish traders). Observations were made to observe the environmental conditions in the Tambak Lorok Fish Market and literature studies were carried out to support research activities. The target of this study is related to parties. The selection of respondents was carried out by a purposive sampling method, which is a method of sampling purposely selected for certain purposes. Determination of priorities that can be applied in processing fish waste in the Tambak Lorok Fish Market area in Semarang City is based on professional judgment, according to the research data and researchers' knowledge based on the results of a review of the literature or documents that support the processing of fish waste. The location of the research study can be seen in Fig. 1.

\subsection{Tools and Materials}

The material used in the study was Google Earth Pro imagery from 2002-2008. The image data is then layout using ArcCIS software 10.4

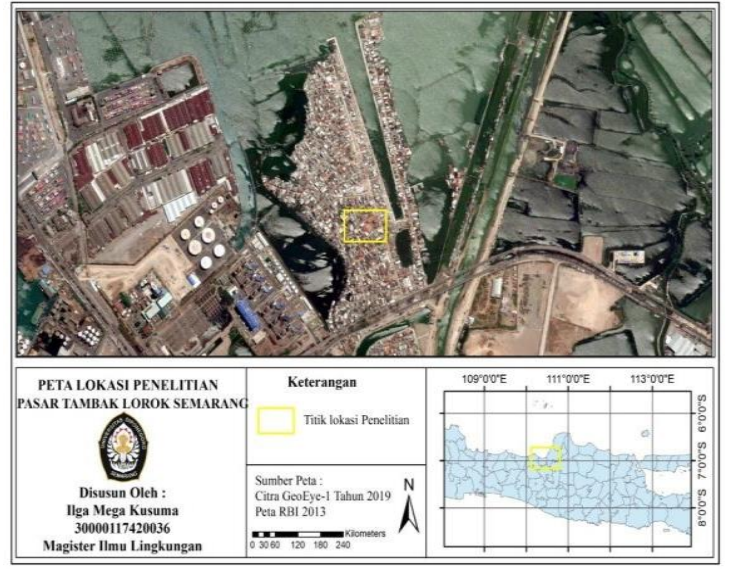

Fig 1. Location of Research Study in Tanjung Mas SubDistrict, Semarang City

\section{Results and Discussion}

\subsection{Environmental Conditions of Tambak Lorok Fish Market Tambak Lorok}

The market is geographically located in Tanjung Mas Village, North Semarang Sub district, which physically consists of TPI (Fish Auction Place) and traditional market, the first floor is for traders of wet fish, dried fish, and meat, while the second floor is for spice and vegetable traders. Market hours start from half past 6 in the morning until 6 in the evening. Around Tambak Lorok Market looks arid. Market conditions still look good because they are moved or allocated to places that have been built by the Semarang city government. There are 72 wet fish traders who occupy the 1 st floor, while on the 2nd floor around 100 traders. Irrigation systems such as tap water and electricity with lights and sockets in each booth have been installed. Facilities that are in the market are mosques and toilets but the conditions are not properly maintained even though the market of Lorok pond has only been used for 4 months. Temporary shelters (TPS) are located behind the market where wet and dry waste is mixed into one in the TPS and there are still some traders who hang fish near TPS. There are still some places where there is plastic waste that is not disposed of in place. This needs to be done between the separation of wet waste (remaining vegetables, leftover fruit, and remaining fish material in the form of fish head, fish meat flakes, fish stomach contents, fish fins and tails) and dry waste (bottles, plastic, rubber, etc.). The role of the government, the community, especially traders who are directly involved in handling the separation of garbage. It is necessary to carry out socialization and concrete actions in dealing with these problems.

\subsection{Processing and Reuse of Fish Waste}

Processing and reusing fish waste is processing and utilizing fish waste that does not have economic value to be a useful thing to be compost. Waste generated 
from traders before being disposed of to TPS should be processed first. Market waste produces more organic waste, which makes it a potential to process compost. In addition to processing organic waste, inorganic waste can also be processed, which can be done in the form of recycling, or reuse.

\subsection{Fish Waste Results}

Composting is done by anaerobic method, where fish waste is used as a starter where fish waste is used as a starter. The level of perfection in the composting process can be seen from the compost maturity. In mature compost the raw material is quite decomposed to produce a stable product.

Table 1. Results of Testing of C-Organic, Nitrogen, Phosphor, and Potassium Levels)

\begin{tabular}{|l|c|c|}
\hline \multicolumn{1}{|c|}{ Parameters } & $\begin{array}{c}\text { Fish Waste } \\
\text { Compost }(\%)\end{array}$ & $\begin{array}{c}\text { SNI Compost } \\
(\%)\end{array}$ \\
\hline C-Organic $(\mathrm{C})$ & 51.7 & $9.80-32$ \\
\hline Nitrogen $(\mathrm{N})$ & 8.3 & 0.40 \\
\hline $\mathrm{C} / \mathrm{N}$ & 6.2 & $10-20$ \\
\hline Phosphor $(\mathrm{P})$ & 4.8 & 0.1 \\
\hline Potassium $(\mathrm{K})$ & 1.6 & $0.20<$ \\
\hline
\end{tabular}

Compost from fish waste has $\mathrm{C} / \mathrm{N}$ lower than the quality of SNI compost, this is caused by organic $\mathrm{C}$ levels analyzed by the gravimetric method. The use of this method results in carbon evaporating as $\mathrm{CO} 2$. For Nitrogen content, compost from fish waste contains $8.25 \%$, this shows much better than SNI compost quality content. Likewise, the level of phosphorus compost from fish waste is $4.73 \%$, this proves that compost from fish waste is good for fertilizer, because plants really need phosphorus in the form of PO4-3, when compared to the SNI compost quality content is only $0.1 \%$. Potassium in plants plays a role in influencing the absorption of other elements. Compost from fish waste has a $1.56 \%$ potassium level, this is very supportive where the greater the potassium level the better for plant growth and development.

\section{Conclusion}

The results showed that the levels of C-Organic; 51.7\%, Nitrogen; 8.3\%, Phosphor; 4.8\%, and Potassium; $1.6 \%$. From the results of C-Organic, Nitrogen, Phosphorus, and Potassium tests, the levels were quite high compared to the quality of SNI compost, so compost from fish waste where the Tambak Lorok Market can be used as fertilizer. Fish waste in Tambak Lorok Market has the potential to be utilized. The potential in the form of utilization of fish waste as raw material for compost fertilizer as an effort to reduce the disposal of fish waste directly into the sea and utilize waste that is not initially beneficial is beneficial for the environment.

\section{References}

1. R.E. Kinnunen, M.C. Gould, P. Cambier, Composting Commercial Fish Processing Waste from Fish Caught in the Michigan Waters of the Great Lakes, Michigan State University Extension : USA (2005)

2. N. Hapsari, T. Welasih, Utilization of fish waste into organic fertilizer, UPN Veteran, Jawa Timur (2010)

3. Selvya, H. Nainggolan, G. Jamahir, B. Wirjosentono, Study of the utilization of fish waste from fish auction sites (tpi) and sibolga traditional markets as compost raw material, Unimal Chemical Technology Journal 2(2), 90 - 99 (2013)

4. Efendi, D. Tiyas, E. Sutrisno, W.D. Nugraha, Studi pemanfaatan limbah fleshing ikan menjadi Kompos dengan menggunakan ulat kandang, Jurnal Teknik Lingkungan 5(2) (2016)

5. A. Syam, Effectiveness of Organic and Inorganic Fertilizers on Rice Productivity in Rice Fields, Agrivigor Journal 3(2), 232-244 (2003)

6. D.R. Setyotini, Saraswati, E.K. Anwar, Journal of Organic Fertilizers and Biofertilizers 2(3), 11-40 (2006) 